\title{
Kajian Molekuler Ikan Oreochromis spp. dari Perairan Daratan Merauke-Papua, Berdasarkan DNA Mitokondria Fragmen Gen Sitokrom Oksidase Subunit I \\ Molecular Study of Oreochromis spp. from Merauke Waterland-Papua, based on mitochondrial DNA Cytochrome Oxidase Subunit I Fragment Gene
}

\author{
Dandi Saleky*1, Reny Sianturi' ${ }^{1}$, Muhammad Dailami \& Aradea Bujana Kusuma ${ }^{3}$ \\ ${ }^{1}$ Departemen Manajemen Sumberdaya Perairan, Fakultas Pertanian, Universitas Musamus Merauke, Merauke, Papua, Indonesia \\ ${ }^{2}$ Program Studi Akuakultur, Fakultas Perikanan dan IImu Kelautan, Universitas Brawijaya, Malang, Jawa Timur, Indonesia \\ ${ }^{3}$ Departemen IImu Kelautan, Fakultas Perikanan dan IImu Kelautan, Universitas Papua, Manokwari, Papua Barat, Indonesia \\ *Penulis korespondensi, email: dandi@unmus.ac.id
}

Tanggal Submisi: 02 November 2020; Tanggal Revisi: 28 April 2021; Tanggal Penerimaan: 05 Mei 2021

\begin{abstract}
ABSTRAK Pemanfaatan perikanan secara lestari sangat diperlukan agar sumberdaya perikanan yang ada saat ini bisa terus dimanfaatkan dan juga dalam rangka pemulihan stok perikanan yang telah rusak. Ikan nila (Oreochromis niloticus) dan ikan mujair (Oreochromis mossambicus) secara luas telah dikenal sebagai salah satu spesies ikan air tawar yang penting dalam perikanan budidaya. Penelitian ini dilakukan dengan tujuan identifikasi spesies ikan Oreochromis spp. dari perairan daratan Merauke dengan menggunakan marka gen COI. Amplifikasi DNA dengan gen COI menghasilkan panjang sekuen DNA 656 bp dengan hasil identifikasi adalah O. niloticus dan O. mussambicus dengan tingkat kemiripan $100 \%$ pada masing-masing spesies. Berdasarkan analisis filogenetik dan jarak genetik, sekuen DNA yang dianalisis membentuk clade sesuai dengn hasil indentfikasi dengan jarak genetik 0,000 - 0,002 pada ikan nila dan 0,000 pada ikan mujair. Analisis keragaman genetik ditemukan hanya 1 haplotype dari kedua jenis ikan tersebut. DNA barcode dan filogenetik dapat digunakan dalam mengidentifikasi spesies dalam pengelolaan dan konservas.

Kata kunci: Filogenetik; Gen COI; jarak genetik; O. niloticus; O. mossambicus

ABSTRACT Sustainable fisheries are needed for long-term usage and restocking of fisheries resources. Nile tilapia $(O$. niloticus) and Mujaer (O. mossambicus) are widely known as an essential freshwater fish in aquaculture. This research aims to analyze the diversity, identification, and species confirmation of Nile Tilapia and Mujaer from Merauke Waterland based on the COI gene. DNA amplification of the COI gene resulted in 656 base pairs of sequence DNA that are identic (100\%) with the sequences of O. niloticus and O. mossambicus from GenBank. The phylogenetic and genetic distance analysis shows that the samples are grouped into two clades following the identification result, with genetic distance vary from 0.000 to 0.002 for $O$. niloticus clade and 0.000 for $O$. mossambicus clade. All samples are grouped into one haplotype, for each species. DNA barcoding and phylogenetic analyses are suitable for genetic identification methods for species conservation and management.
\end{abstract}

Keywords: Phylogenetic; COI gene; genetic distance; O. niloticus; O. mossambicus

\section{PENDAHULUAN}

Pemanfaatan perikanan secara lestari sangat diperlukan agar sumberdaya perikanan yang ada saat ini bisa terus dimanfaatkan dan juga dalam rangka pemulihan stok perikanan yang telah rusak (Ward, 2000; Garcia \& Rosenberg, 2010). Pengelolaan dan konservasi suatu spesies memerlukan berbagai infomasi seperti informasi ekologi, morfologi dan juga informasi genetik dan taksonomi (Nuryanto \&Solihin, 2006; Panprommin etal., 2019). Perubahan kondisi lingkungan serta laju pemanfaatan sumberdaya yang berlebih dapat menyebabkan perubahan komposisi spesies serta penurunan keragaman genetik pada suatu populasi (Kusuma et al., 2016) termasuk populasi ikan Oreochromis spp.

Ikan Oreochromis spp. sangat melimpah di perairan daratan Merauke, oleh masyarakat umum di kota Merauke ikan Orecohromis spp. tersebut diidentifikasi dengan jenis ikan mujair. Ikan Oreochromis spp. sangat digemari oleh masyarakat sebagai sumber protein selain harganya yang relatif terjangkau tetapi juga jumlahnya sangat melimpah di alam. Ikan nila (Oreochromis niloticus) dan ikan mujair (Oreochromis mossambicus) secara luas telah dikenal sebagai salah satu spesies ikan air tawar yang penting dalam perikanan budidaya (Gunadi et al., 2016; Ordoñez et al., 2017). Ikan tersebut menjadi komoditas penting karena memiliki toleransi yang tinggi terhadap kondisi lingkungan dengan tingkat pertumbuhan yang cepat (Nakkina, 2016; Yustysi et al., 2016). Selain itu ikan tersebut juga mudah untuk dipijahkan (Pantow et al., 2017). Ikan nila dan ikan mujair merupakan ikan invasive di berbagai wilayah perairan daratan dan percampuran genetik sering terjadi antara keduanya yang menyebabkan terjadinya penurunan keragaman genetik akibat terjadinya hibridisasi (Firmat et al., 2013; Hänfling, 2007). Semakin tingginya ancaman terhadap populasi membuat penurunan keanekaragaman genetik diperkirakan menurun lebih cepat dibandingkan dengan keanekaragaman spesies, dan secara global distribusi keragaman genetik kurang terdokumentasikan dengan 
baik (Manel etal., 2020).

Penurunan keanekaragaman genetik ikan air tawar dapat disebabkan beberapa faktor seperti invasive spesies (Wargasasmita, 2005), hibridisasi (Firmat et al., 2013), degradasi habitat dan pencemaran lingkungan (Shechonge et al., 2018). Penurunan kualitas lingkungan dan parasit juga turut memengaruhi keanekaragaman genetik (Arini et al., 2018). Data genetik dapat memberikan kontribusi penting dalam pemahaman konektivitas populasi, strategi konservasi dan pengelolaan, termasuk di dalamnya penentuan daerah konservasi (Díaz-Ferguson et al., 2010). Analisis kekerabatan, sejarah evolusi maupun dinamika evolusi dapat dipelajari melalui rekonstruksi filogenetik (Sohpal, 2013; Rumanta et al., 2020). Pendekatan filogenetik molekuler telah banyak dilakukan dalam mengidentifikasi spesies ikan (Jefri et al., 2015; Saleky et al., 2020; Dailami et al., 2021). Filogenetik molekuler dengan DNA mitokondria dapat membedakan dan mengidentifikasi spesies yang secara morfologi sulit dilakukan (Hebert et al., 2003).

Analisis jarak dan variasi genetik sangat penting dilakukan dalam menganalisis diferensiasi gen antar populasi guna mendukung kegiatan konservasi dan perbaikan stok perikanan di alam (Doğan \& Doğan, 2016; Kibria et al., 2014). Keragaman genetik populasi juga dapat digunakan sebagai acuan dalam menetukan sumber varian baru dalam program pemuliaan ikan (Arifin \& Kurniasih, 2016; Ordoñez et al., 2017). Variasi genetik suatu populasi dapat dipertahankan atau ditingkatkan dengan melakukan introduksi varian genetik baru dari populasi dengan variasi genetik yang lebih beragam (Hänfling, 2007). Keragaman genetik spesies air tawar sangat bervariasi terutama pada daerah aliran sungai dan kemiringan sungai menjadi salah satu faktor pembatas keragaman genetik pada daerah aliran sungai (Manel et al., 2020).

Gen mitokondria sitokrom c oksidase 1 (COI) menjadi pendekatan molekuler yang umum digunakan secara luas dalam identifikasi spesies (Sun et al., 2016; Ward, 2000; Zemlak et al., 2009). Selain itu, gen COI telah banyak digunakan dalam berbagai studi keragaman genetik dan klasifikasi spesies (Hebert et al., 2003), rekonstruksi filogenetik (Leatemia et al., 2018), konektivitas genetik regional dalam kegiatan konservasi dan pengelolaan organisme (Díaz-Ferguson et al., 2010).

Melimpahnya sumberdaya ikan Oreochromis spp. di alam membuat identifikasi molekuler menjadi sangat penting untuk dilakukan (Layton et al., 2014) karena identifikasi dengan pendekatan DNA barcoding dapat membedakan spesies secara cepat dan akurat (Saleky et al., 2020). Belum adanya studi tentang DNA barcoding dan keragaman genetik ikan Oreochromis spp. di perairan daratan Merauke, membuat penelitian ini sangat penting untuk dilakukan dalam rangka pengelolaan perikanan secara berkelanjutan dan kegiatan konservasi ekosistem (Ward etal., 2005).

\section{BAHAN DAN METODE}

\section{Lokasi dan waktu pengambilan sampel}

Sebanyak 11 sampel ikan Oreochromis sp. dikoleksi dari 3 lokasi perairan daratan di Merauke yaitu Rawa Barki, Sungai Bian dan Sungai Blorep Merauke (Gambar 1).
Identifikasi morfologi ikan dilakukan dengan menggunakan fishbase (www.fishbase.org). Jaringan sirip yang didapatkan kemudian disimpan dalam botol sampel berisi ethanol 96 $\%$. Sampel jaringan sirip yang telah diperoleh kemudian dikirim ke Laboratorium Biodiversitas Indonesia (BIONESIA) Bali untuk dilakukan analisis molekuler agar dapat diperlolah fragmen gen COI.

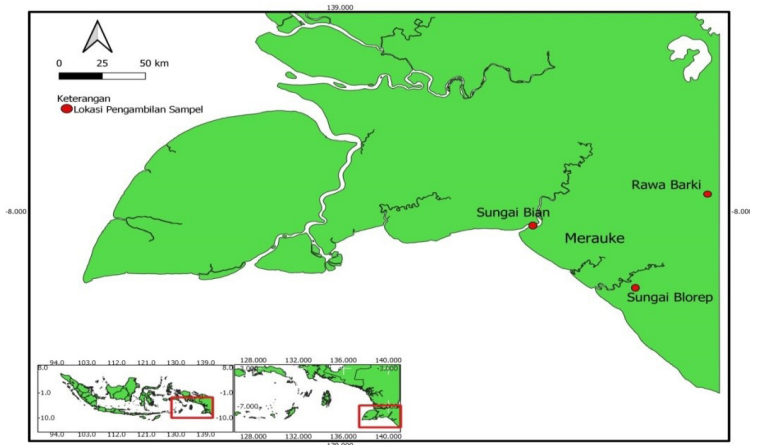

Gambar 1. Peta lokasi pengambilan sampel (titik-titik merah merupakan lokasi pengambilan sampel).

\section{Analisis molekuler}

Ekstraksi DNA menggunakan sampel jaringan sirip ikan dengan menggunakan chelex 10\% (Walsh et al., 2018). Keberhasilan ekstrasi DNA tidak dihitung secara kuantitatif tertapi secara kualitatif yangmana hasil ekstrasi DNA genom terlebih dahulu dielektroforesis, indikator keberhasilan dilihat dengan munculnya pita DNA pada hasil elektroforesis. Reaksi PCR menggunakan volume $25 \mu \mathrm{l}$ dengan jumlah template DNA 1-4 $\mu$ l. Primer yang digunakan dalam penelitian ini menggunakan 2 primer yaitu primer forward FISH-BCH: 5'-TCAACCAACCACAAAGACA-3', dan primer FISH-BCL reverse: 5' TAGACTTCTGGGTGGCCAA-3' (Ward et al., 2005). Profil PCR meliputi denaturasi awal $94^{\circ} \mathrm{C}$ selama 15 detik, denaturasi $94^{\circ} \mathrm{C}$ selama 30 detik, annealing pada $50^{\circ} \mathrm{C}$ selama 30 detik dan extention pada $72^{\circ} \mathrm{C}$ selama 45 detik dan final extention pada $72^{\circ} \mathrm{C}$ selama 10 menit, semua proses tersebut dilakukan dengan pengulangan sebanyak 40 siklus. Hasil PCR kemudian dielektroforesis untuk memvisualisasikan hasil amplifikasi fragmen gen COI. Proses ini dilakukan dengan menggunakan gel agarosa $1 \%(b / v)$, yaitu dengan mencampurkan 0,5 gram agarosa dalam $45 \mathrm{~mL}$ SBBuffer. Hasil PCR positif kemudian dikirim ke lembaga sekuensing 1st (Malaysia) untuk mendapatkan urutan pasang basa DNA.

\section{Analisis data}

Hasil sekuensing DNA yang diperoleh kemudian diedit menggunakan model ClustalW (1.6) (Kumar et al., 2016) dengan menggunakan program MEGA 7 (Molecular Evolutionary Genetic Analysis). Data yang telah diedit kemudian dicocokkan dengan data genetik pada GeneBank di NCBI (National Center for Biotechnology Information) dengan menggunakan BLAST (Basic Local Alignment Search Tool). Perhitungan jarak genetik (D) antar spesies dihitung dan juga merekonstruksi pohon filogenetik dengan menggunakan aplikasi Mega 7 (Kumar et al., 2016) dengan metode Neighbour-Joining (NJ) dengan model Kimura 2-parameter, nilai bootstrap 1000x. Spesies 0 . aureus digunakan sebagai out grup dalam analisis filogenetik. Analisis sebaran haplotipe dengan menggunakan Software DNAsp 5.0 (Rozas et al., 2003). Analisis filogenetik 
filogenetik dilakukan dengan menngunakan sekuen DNA ikan Oreochromis spp. hasil penelitian ini ditambah dengan sekuen COI Oreochromis spp. yang didownload dari genbank sebagai pembanding (Tabel 1). mujair (O. mossambicus) melainkan juga terdapat jenis ikan nila (O. niloticus). Kedua jenis ikan hidup pada habitat sama yang dapat mengakibatkan terjadinya hibridisasi (percampuran genetik) antar kedua spesies tersebut.

Tabel 1. Sekuen DNA Oreochromis spp. yang digunakan dalam rekontruksi filogenetik termasuk lokasi, nomor akses dari National Center for Biotechnology Information (NCBI).

\begin{tabular}{cllll}
\hline No & \multicolumn{1}{c}{ Spesies } & \multicolumn{1}{c}{ Lokasi } & \multicolumn{1}{c}{ Acc. Number } & \multicolumn{1}{c}{ Sumber } \\
\hline 1 & O. mossambicus & Tasikmalaya & KU692685 & Dahruddin etal. (2017) \\
2 & O. mossambicus & Lumajang & KU692683 & Dahruddin et al. (2017) \\
3 & O. mossambicus & Lumajang & KU692693 & Dahruddin etal. (2017) \\
4 & O. mossambicus & Bali & KU692691 & Dahruddin et al. (2017) \\
5 & O. mossambicus & Bali & KU692692 & Dahruddin et al. (2017) \\
6 & O. mossambicus & Bali & KU692689 & Dahruddin et al. (2017) \\
7 & O. mossambicus & Bali & KU692688 & Dahruddin et al. (2017) \\
8 & O. mossambicus & Ambarawa & KU692684 & Dahruddin et al. (2017) \\
9 & O. mossambicus & Indonesia & KU692686 & Dahruddin et al. (2017) \\
10 & O. mossambicus & Ambarawa & KU692687 & Dahruddin etal. (2017) \\
11 & O. niloticus & Indonesia & HM345941 & Muchlisin et al. (2013) \\
12 & O. niloticus & Indonesia & HM345942 & Muchlisin et al. (2013) \\
13 & O. niloticus & Indonesia & KU692694 & Dahruddin et al. (2017) \\
14 & O. niloticus & Indonesia & KP856792 & Abdullah \& Rehbein, (2017) \\
15 & O. aureus & Filipina & KU565852 & Ordoñez et al. (2017) \\
\hline
\end{tabular}

\section{HASIL DAN PEMBAHASAN}

Karaktermolekuler

Sebanyak 11 sampel ikan Oreochromis spp. dikoleksi dari 3 lokasi di perairan daratan Merauke yaitu Rawa Barki, Sungai Bian dan Sungai Blorep. Berdasarkan karakter morfologi, tidak dapat didentifikasi sampai pada tingkatan spesies tetapi sampai pada tingkatan genus. Hal tersebut akibat miripnya morfologi dari ikan Oreochromis spp. yang dikoleksi. Keseluruhan sampel tersebut secara umum disebut dengan ikan mujair oleh masyarakat umum di Kota Merauke. Ikan-ikan tersebut memiliki ukuran tubuh yang cukup besar dengan ukuran $20-40 \mathrm{~cm}$. Berdasarkan hasil identifikasi dengan marka gen COI, diketahui di perairan daratan Merauke terdiri atas 2 jenis anggota genus Oreochromis spp. yaitu ikan nila (Oreochromis niloticus) dan ikan mujair (Oreochromis mossambicus).

Berdasarkan hasil identifikasi mengunakan BLAST (Basic Local Alignment Search Tool) pada National Center for Biotechnology Information (NCBI) adalah ikan nila (O. niloticus). dan ikan mujair (O. mossambicus) dengan tingkat kemiripan 100\% (Tabel 2). Hasil ini membuktikan bahwa ikan Oreochromis spp. yang hidup dan melimpah di perairan daratan Merauke bukan hanya jenis ikan

\section{(Firmat et al., 2013).}

Kesalahan identifikasi wajar terjadi akibat adanya kesamaan morfologi yang disebabkan oleh fenomena cryptic species maupun siblings species (Purnamasari et al., 2016). Berdasarkan karakter morfologi kedua jenis tersebut memiliki morfologi yang sangat mirip (Khayra et al., 2016). Umumnya ikan diidentifikasi dengan pendekatan morfologi tetapi dalam banyak kasus banyak spesies yang mirip tidak dapat diidentifikasi pada tahapan perkembangan tertentu sehingga dibutuhkan identifikasi dengan pendekatan DNA barcoding (Jefri et al., 2015).

Variasi genetik menjadi kunci penting pada suatu populasi dalam bertahan pada lingkungannya (Kusuma et al., 2016). Variasi genetik menjadi elemen penting dalam kegiatan konservasi (Kenchington, 2010). Analisis keragaman genetik ditemukan 1 haplotipe baik pada ikan nila (O. niloticus) ataupun pada ikan mujair ( 0 . mossambicus) (Tabel 3).

Haplotipe ikan nila (O. niloticus) dan mujair (O. mossambicus) masing - masing terdiri atas 1 haplotipe yang menunjukkan garis keturunan haplotipe yang sama antara perairan Merauke dan beberapa wilayah di Indonesia. Haplotipe yang identik tersebut terjadi karena tidak adanya mutasi

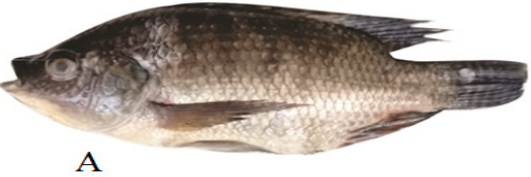

A

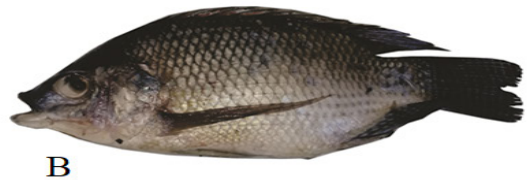

B

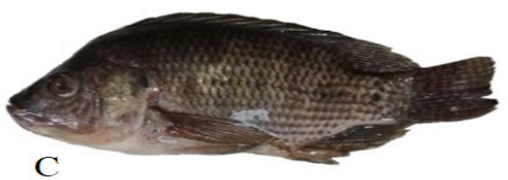

$\mathrm{C}$

Gambar 2. Morfologi Oreochromis spp. yang dikoleksi dari Rawa Barki (A), Sungai Bian (B) dan Sungai Blorep (C). 
Tabel 2. Hasil identifikasi spesies menggunakan BLAST (Basic Local Alignment Search Tool) di National Center for Biotechnology Information (NCBI).

\begin{tabular}{clllc}
\hline No & \multicolumn{1}{c}{ Sampel Id } & \multicolumn{1}{c}{ Spesies } & \multicolumn{1}{c}{ Lokasi } & Hasil Blast (\%) \\
\hline 1 & Rawa Barki 1 & O. mossambicus & Rawa Barki, Merauke & 100 \\
2 & Rawa Barki 2 & O. niloticus & Rawa Barki, Merauke & 100 \\
3 & Rawa Barki 3 & O. niloticus & Rawa Barki, Merauke & 100 \\
4 & Rawa Barki 4 & O. niloticus & Rawa Barki, Merauke & 100 \\
5 & Sungai Bian 1 & O. niloticus & Sungai Bian, Merauke & 100 \\
6 & Sungai Bian 2 & O. mossambicus & Sungai Bian, Merauke & 100 \\
7 & Sungai Bian 3 & O. niloticus & Sungai Bian, Merauke & 100 \\
8 & Sungai Bian 4 & O. niloticus & Sungai Bian, Merauke & 100 \\
9 & Blorep 1 & O. mossambicus & Blorep, Merauke & 100 \\
10 & Blorep 2 & O. niloticus & Blorep, Merauke & 100 \\
11 & Blorep 3 & O. mossambicus & Blorep, Merauke & 100 \\
\hline
\end{tabular}

Tabel 3. Sebaran haplotipe ikan mujair (O. mossambicus) dan ikan nila (O. niloticus) di perairan daratan Merauke.

\begin{tabular}{ccccc}
\hline Haplotipe/ & \multicolumn{3}{c}{ Lokasi PengambilanSampel } & \multirow{2}{*}{ Total haplotipe } \\
\cline { 2 - 4 } O. mossambicus & RawaBarki & SungaiBian & Blorep & \\
\hline H1 & 1 & 1 & 1 & 1 \\
\hline \multirow{2}{*}{ Haplotipe/O. niloticus } & \multicolumn{3}{c}{ Lokasi PengambilanSampel } & Total haplotipe \\
\cline { 2 - 4 } & Rawarki & SungaiBian & Blorep & 1 \\
\hline H1 & 1 & 1 & 1 & 1 \\
\hline
\end{tabular}

yang terjadi pada ikan mujair (O. mossambicus) ataupun ikan nila (O. niloticus) yang tersebar pada perairan daratan Merauke. Haplotipe ikan nila asal Merauke dan beberapa wilayah di Indonesia terdiri atas 3 haplotipe, sebaliknya pada ikan mujair hanya terdapat 1 haplotipe. Kesamaan haplotipe Oreochromis spp. asal Merauke dengan daerah lainnya terjadi karena jenis tersebut merupakan satu garis keturunan yang sama yangmana jenis tersebut bersifat invasive yang kemudian menjadi komoditas penting dalam bidang perikanan khususnya pada perairan daratan di Kota Merauke dan berbagai wilayah lainnya.

Kesamaan haplotipe ikan nila (O. niloticus) dan ikan mujair (O. mossambicus) asal perairan Merauke dengan berbagai wilayah lainnya memungkinan individu-individu pada kedua spesies tersebut tidak memiliki perbedaan spesifik dari komposisi asam amino maupun jajaran sekuen DNA. Hasil analisis haplotipe ini dapat digunakan dalam mengurangi tekanan pada populasi alami melalui proses domestikasi dan peningkatan produksi melalui pemuliaan selektif dengan cara mengambil sumber genetik baru dari populasi yang memiliki variasi genetik yang berbeda dengan populasi asal (Wibowo et al., 2010).

\section{Jarakgenetik}

Jarak genetik digunakan untuk melihat kedekatan hubungan genetik antar individu suatu spesies dengan indvidu dan spesies lainnya (Suriana et al., 2019). Analisis jarak genetik sangat berkaitan dengan rekonstruksi pohon filogenetik yang terbentuk. Jarak genetik (Tabel 4) antara ikan nila (O. niloticus) dan mujair (O. mossambicus) sebesar 0,054, sedangkan jarak genetik terjauh antara ikan nila $(0$. niloticus) dengan ikan Oreochromis aureus sebesar 0.077 .

Spesies yang memiliki nilai jarak genetik yang rendah mengindikasikan bahwa spesies tersebut memiliki hubungan kekerabatan yang semakin dekat. Sebaliknya, semakin besar nilai jarak genetik mengindikasikan hubungan kekerabatan yang semakin jauh. Ikan nila ( $O$. niloticus) dan ikan mujair (O. mossambicus) memiliki jarak genetik yang cukup tinggi, tetapi secara morfologi kedua spesies tersebut memiliki kimiripan morfologi. Kemiripan morfologi ini dapat terjadi karena terjadinya hibridisasi (percampuran genetik) akibat kedua spesies tersebut hidup secara bersama di alam (Arifin \& Kurniasih, 2016; Gabaldón etal., 2013).

Tabel 4. Jarak genetik Oreochromis spp.

\begin{tabular}{|c|c|c|c|}
\hline No & Spesies & 1 & 2 \\
\hline 1 & Oreochromis mossambicus & * & * \\
\hline 2 & Oreochromis niloticus & 0,054 & * \\
\hline 3 & Oreochromis aureus & 0,073 & 0,077 \\
\hline
\end{tabular}




\section{Rekonstruksi pohon filogenetik}

Pendekatan filogenetik molekuler dapat digunakan untuk membedakan dan mengidentifikasi spesimen yang sulit diidentifikasi (Jefri et al., 2015). Rekonstruksi pohon filogenetik molekuler memanfaatkan data biomolekuler struktural atau fungsional yang dapat digunakan untuk konstruksi pohon filogenetik (Pardi et al., 2016; Rumanta et al., 2020). Rekonstruksi filogenetik dalam penelitian ini terdiri dari 26 sekuen COI Oreochromis spp. menggunakan metode Neighbor-Joining (NJ) dengan model Kimura 2-parameter, bootstrap 1000x (Gambar 3).

Rekonstruksi filogenetik memperlihatkan keseluruhan sekuen terpisah berdasarkan jenis dan kemiripan sekuen. Pohon filogenetik yang terbentuk terbagi atas 3 clade yaitu clade Oreochromis niloticus, clade Oreochromis mossambicus dan clade Oreochromis aureus. Percampuran tersebut juga didukung oleh nilai jarak genetik keseluruhan ikan nila yang berkisar 0,000 - 0,0002. percampuran yang sama juga terjadi pada sekuen ikan mujair yang dianalisis, percampuran tersebut didukung oleh nilai jarak genetik 0,000 pada semua sekuen DNA ikan mujair dengan 1 haplotipe yang identik. Hasil analisis tersebut memperlihatkan bahwa ikan mujair yang berasal dari perairan daratan Merauke memiliki garis keturan yang sama dengan ikan mujair yang berasal dari daerah lainnya. Rekonstruksi filogenetik juga berhasil membedakan antar spesies ikan nila dan ikan mujair yangsulit dilakukan melalui kajian morfologi.
Ikan Oreochromis spp. termasuk ikan invasive yang sangat melimpah di alam dan mengganggu keberadaan ikan endemik di perairan daratan Merauke. Hasil analisis juga memperlihatkan keaneragaman genetik Ikan Oreochromis spp. sangat rendah di alam, hal tersebut membuat keberadaan populasinya menjadi terancam. Didukung pula dengan status konservasi ikan mujair (O. mossambicus) di The International Union for Conservation of Nature (IUCN) (https://www.iucnredlist. org/) pada habitat asalnya di Afrika berada dalam kategori vulnerable yang berarti spesies tersebut menghadapi risiko kepunahan di alam liar di waktu yang akan datang. Berbeda dengan ikan mujair (O. mossambicus) status konservasi ikan nila ( $O$. niloticus) pada habitat asalnya di Afrika termasuk dalam kategori least concern yang berarti beresiko rendah atau masih dianggap aman di habitat asalnya. Walaupun terancam di habitat asalnya, ikan mujair (0. mossambicus) termasuk ikan predator di perairan Merauke. Kehadiran ikan Oreochromis spp. di perairan daratan Merauke menyebabkan berkurangnya jumlah ikan endemik di Merauke seperti ikan pelangi (Melanotaenia sp.) dan Oxyeleotris fimbriata yang memiliki ukuran tubuh yang lebih kecil.

\section{KESIMPULAN}

Analisis DNA barcoding dapat mengidentifikasi 2 spesies anggota genus Oreochromis yang hidup di perairan daratan Merauke yaitu ikan nila (Oreochromis niloticus) dan ikan mujair (Oreochromis mossambicus). Analisis

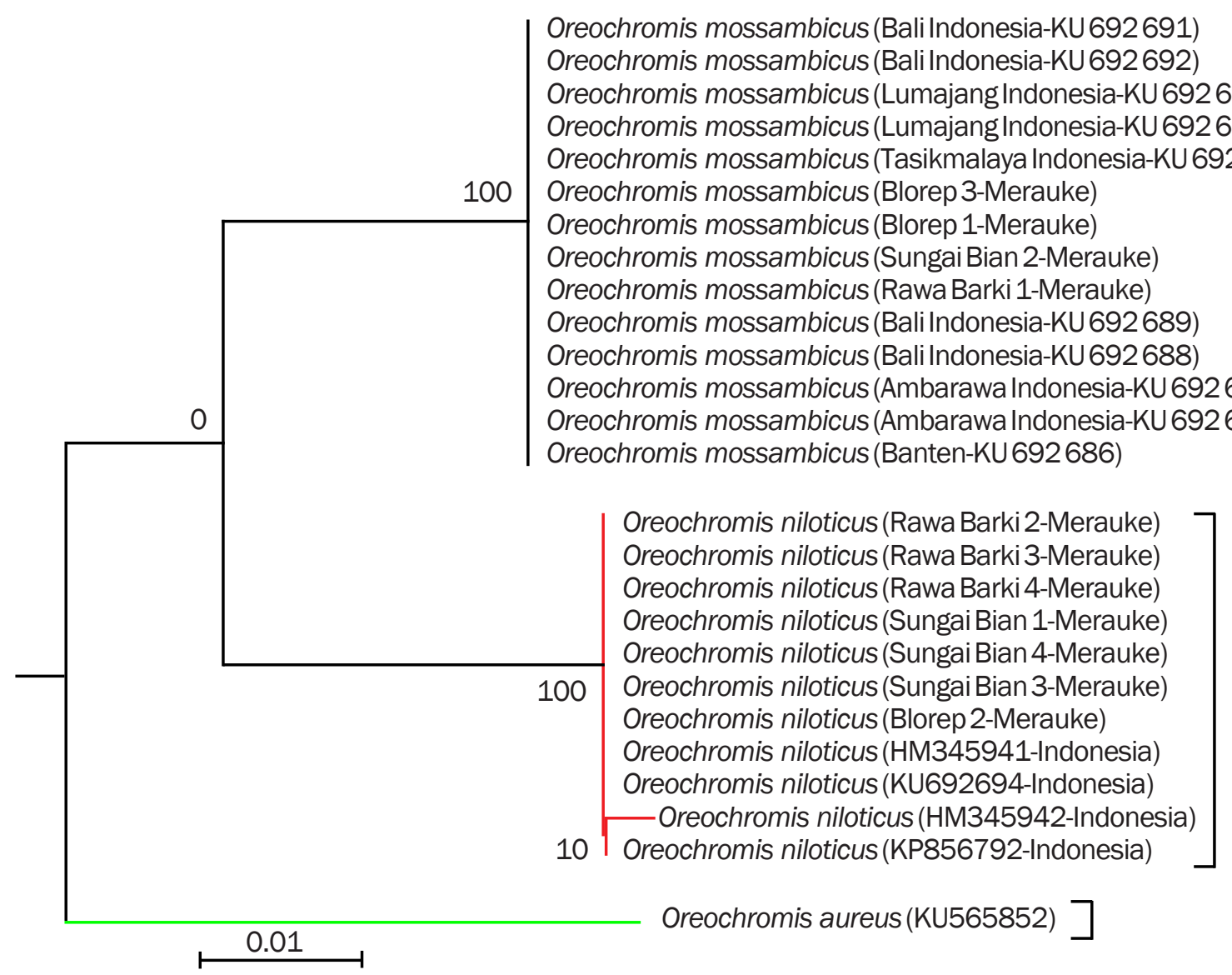

Gambar 3. Rekonstrukti pohon filogenetik menggunakan metode Neighbor-Joining (NJ) dengan model Kimura 2-parameter, bootstrap 1000x. 
filogenetik dan keragaman genetik seluruh sampel yang dianalissi memiliki 1 haplotipe dengan jarak genetik 0,000 - 0,0032 pada ikan nila sedangkan pada ikan mujair seluruh sampel memiliki jarak genetik 0,000. DNA barcode dapat digunakan dalam mengidentifikasi dan konfirmasi spesies dalam pengelolaan dan konservasi spesies.

\section{DAFTAR PUSTAKA}

Abdullah, A \& H. Rehbein. 2017. DNA barcoding for the species identification of commercially important fishery products in Indonesian markets. International Journal of Food Science and Technology, 52 (1): 266-274. https://doi.org/10.1111/ijfs.13278.

Arifin, 0.Z \& T. Kurniasih. 2016. Variasi genetik tiga populasi ikan nila (Oreochromis niloticus) berdasarkan polimorfisme mt-DNA. Jurnal Riset Akuakultur. 2 (1): 67. https://doi.org/10.15578/jra.2.1.2007.67-75.

Dahruddin, H., A. Hutama, F. Busson, S. Sauri, R. Hanner, P. Keith, R. Hadiaty \& N. Hubert. 2017. Revisiting the ichthyodiversity of Java and Bali through DNA barcodes: taxonomic coverage, identification accuracy, cryptic diversity and identification of exotic species. Molecular Ecology Resources. 17 (2): 288-299. https://doi.org/10.1111/1755-0998.12528.

Dailami, M., Y. Widyawati \& A.H.A. Toha. 2021. Identifikasi genetik ikan teri dari Teluk Cenderawasih dengan pendekatan DNA Barcoding. Musamus Fisheries and Marine Journal. 3 (2): 154-166. https://doi. org/10.35724/mfmj.v3i2.3521.

Díaz-Ferguson, E., R. Haney, J. Wares \& B. Silliman. 2010. Population genetics of a trochid gastropod broadens picture of caribbean sea connectivity. PLoS ONE, 5 (9): 1-8. https://doi.org/10.1371/journal.pone.0012675.

Doğan, ì \& N. Doğan. 2016. Genetic distance measures: Review. Turkiye Klinikleri Journal ofBiostatistics. 8(1):8793. https://doi.org/10.5336/biostatic.2015-49517.

Firmat, C., Alibert, P., Losseau, M., Baroiller, J. F., \& Schliewen, U. K. 2013. Successive invasion-mediated interspecific hybridizations and population structure in the endangered cichlid Oreochromis mossambicus. PLoS ONE. 8 (5). https://doi.org/10.1371/journal. pone.0063880.

Gabaldón, C., J. Montero-Pau, M. Serra \& M.J. Carmona. 2013. Morphological similarity and ecological overlap in two rotifer species. PLoS ONE. 8(2): 23-25. https:// doi.org/10.1371/journal.pone.0057087.

Garcia, S.M \& A.A. Rosenberg. 2010. Food security and marine capture fisheries: Characteristics, trends, drivers and future perspectives. In Philosophical Transactions of the Royal Society B: Biological Sciences. 365 (1554): 2869-2880. Royal Society. https://doi.org/10.1098/rstb.2010.0171.

Gunadi, B., A. Robisalmi \& P. Setyawan. 2016. Performa pertumbuhan dan estimasi nilai heterosis juvenil ikan nila (Orochromis niloticus), ikan nila biru (Oreochromis aureus) dan persilangannya yang dipelihara di kolam air tawar. Prosiding Forum Inovasi Tekonologi Akuakultur. 571-577.
Hänfling, B. 2007. Understanding the establishment success of non-indigenous fishes: Lessons from population genetics. Journal of Fish Biology. 71 (SUPPL. D), 115-135. https://doi.org/10.1111/ j.1095-8649.2007.01685.x.

Hebert, P., A. Cywinska, S. Ball \& J. deWaard. 2003. Biological identifications through DNA barcodes. Proc R Soc Lond B Biol Sci, 270.

Hebert, P.D.N., A. Cywinska, S.L. Ball \& J.R. DeWaard. 2003. Biological identifications through DNA barcodes. Proceedings of the Royal Society B: Biological Sciences. 270 (1512): 313-321. https://doi.org/ 10.1098/ rspb.2002.2218.

Jefri, E., N.P. Zamani, B. Subhan \& H.H. Madduppa. 2015. Molecular phylogeny inferred from mitochondrial DNA of the grouper Epinephelus spp. In Indonesia collected from local fish market. Biodiversitas. 16 (2): 254-263. https://doi.org/10.13057/biodiv/d160221.

Kenchington, E.L. 2010. The effects of fishing on species and genetic diversity. Responsible Fisheries in the Marine Ecosystem. 235-253. https://doi. org/10.1079/9780851996332.0235.

Khayra, A., Z.A. Muchlisin \& M.A. Sarong. 2016. Morfometrik lima spesies ikan yang dominan tertangkap di Danau Aneuk Laot, Kota Sabang. DEPIK Jurnal IImu-IImu. 5 (2): 57-66. http://jurnal.unsyiah.ac.id/depik/article/ view/4907.

Kibria, Md.G., Sweety, A.J, Md. S. Islam \& Md.S. Alam. 2016. Population genetic structure of the nile tilapia (Oreochromis niloticus) revealed by microsatellite DNA marker analysis. J. Aqua Trop. 29 (1-2): 9-19.

Kumar, S., G. Stecher \& K. Tamura. 2016. MEGA7: Molecular evolutionary genetics analysis version 7.0 for bigger datasets. Molecular Biology and Evolution. 33 (7): 1870-1874. https://doi.org/ 10.1093/molbev/msw054.

Kumar, S.V. 2013. Computational analysis of distance and character based phylogenetic tree for capsid proteins of human herpes virus. Journal of Data Mining in Genomics \& Proteomics. 4 (02). https://doi. org/10.4172/2153-0602.1000128.

Kusuma, A.B., D.G. Bengen, H.H. Madduppa, B. Subhan \& D. Arafat. 2016. Keanekaragaman genetik karang lunak Sarcophyton trocheliophorum pada populasi laut Jawa, Nusa Tenggara dan Sulawesi. Jurnal Enggano. 1 (1): 89-96. https://doi.org/10.31186/ jenggano.1.1.89-96.

Layton, K.K.S., A.L. Martel \& P.D. Hebert. 2014. Patterns of DNA barcode variation in canadian marine molluscs. PLoS ONE. 9 (4), e95003. https://doi.org/10.1371/ journal.pone.0095003.

Leatemia, S.P., A.W. Manumpil, D. Saleky \& M. Dailami. 2018. DNA barcode dan molekuler filogeni Turbo sp. di Perairan Manokwari Papua Barat. Prosiding Seminar Nasional MIPA UNIPA. 3 (1): 103-114. https://prosiding.fmipa.unipa.ac.id/index.php/ SNMIPAUNIPA/article/view/12.

Manel, S., P.E. Guerin, D. Mouillot, S. Blanchet, L. Velez, C. Albouy \& L. Pellissier. 2020. Global determinants 
of freshwater and marine fish genetic diversity. Nature Communications. 11 (1): 1-9. https://doi.org/10.1038/ s41467-020-14409-7.

Muchlisin, Z.A., Z. Thomy, N. Fadli, M.A. Sarong \& M.N.S. Azizah. 2013. DNA barcoding of freshwater fishes from Lake Laut Tawar, Aceh Province, Indonesia. Acta Ichthyologica et Piscatoria. 43 (1): 21-29. https://doi. org/10.3750/AIP2013.43.1.04.

Nakkina, M. 2016. Study of growth rate in nile tilapia (Oreochromis niloticus). Journal of Aquaculture Research \& Development. 7 (8): 8-11. https://doi. org/10.4172/2155-9546.1000440.

Nuryanto, A \& D.D. Solihin. 2006. Variasi sekuens gen mitokondrial sitokrom C Oksidase I (COI) dari siput lola (Trochus niloticus). Biosfera. 23 (1): 31-37.

Ordoñez, J.F.F., M.F.H. Ventolero \& M.D. Santos. 2017. Maternal mismatches in farmed tilapia strains (Oreochromis spp.) in the Philippines as revealed by mitochondrial COI gene. Mitochondrial DNA Part A: DNA Mapping, Sequencing, and Analysis. 28 (4): 526-535. https://doi.org/10.3109/24701394.201 6.1149824.

Panprommin, D., K. Soontornprasit, S. Tuncharoen, S. Pithakpol \& J. Keereelang. 2019. DNA barcodes for the identification of species diversity in fish from Kwan Phayao, Thailand. Journal of Asia-Pacific Biodiversity. 12 (3): 382-389. https://doi.org/10.1016/j. japb.2019.05.003.

Pantow, J.G.L., S. Suhaeni \& M. Wasak. 2017. Analisis usaha budidaya ikan nila pada CV Tiga Mas di Desa Talawaan Kecamatan Talawaan Kabupaten Minahasa Utara. Akulturasl (Jurnal IImiah Agrobisnis Perikanan). 5 (9). https://doi.org/10.35800/ akulturasi.5.9.2017.16979.

Pardi, F., O.Gascuel, F. Pardi \& O. Gascuel. 2016. Distancebased methods in phylogenetics To cite this version : Encyclopedia of Evolutionary Biology. 458-465..

Purnamasari, L., A. Farajallah \& D. Wowor. 2016. Application of DNA barcode in determination of shrimp species of fresh water from the Province of Jambi. Biocencetta. 2 (1): 50-59.

Rumanta, M., R.M. Kunda, S.D. Volkandari, I. Indriawati \& P. Kakisina. 2020. Genetic characterization and phylogeneticstudy of Lakor goat from Southwest maluku regency based on mitochondrial COI gene. Veterinary World. 13 (6): 1209-1220. https://doi. org/10.14202/vetworld.2020.1209-1220.

Saleky, D., S.P.O. Leatemia, T.F. Pattiasina, I. Isma, R.D. Pangaribuan, M.A. Welliken, E.H.P. Melmambessy \& M. Dailami. 2020. Analisis pola pertumbuhan dan pendekatan DNA barcoding untuk identifikasi Turbo stenogyrus P. Fischer, 1873 (Mollusca: Gastropoda). Biotropika - Journal of Tropical Biology. 8 (2): 79-86. https://doi.org/10.21776/ub.biotropika.2020.008. 02.03.

Sun, S., Q. Li, L. Kong, H. Yu, X. Zheng, R. Yu, L. Dai, Y. Sun, J. Chen, J. Liu, L. Ni, Y. Feng, Z. Yu, S. Zou \& J.
Lin. 2016. DNA barcoding reveal patterns of species diversity among northwestern Pacific molluscs. Scientific Reports, 6(August), 1-17. https://doi.org/10.1038/ srep33367.

Suriana, S., M. Marwansyah \& A. Amirullah, A. 2019. Karakteristik segmen gen sitokrom C oksidase subunit I (COI) ngengat Plusia chalcites (Lepidoptera: Noctuidae). BioWallacea : Jurnal Penelitian Biologi (Journal of Biological Research). 6 (2): 985. https://doi. org/10.33772/biowallacea.v6i2.8824.

Walsh, P.S., D.A. Metzger \& R. Higuchi. 2018. Chelex 100 as a medium for simple extraction of DNA for PCR-based typing from forensic material. BioTechniques. 54 (3): 506-513. https://doi.org/10.2144/000114018.

Ward, R.D. 2000. Genetics in fisheries management. Hydrobiologia. 420 (1): 191-201. https://doi. org/10.1023/A:1003928327503.

Ward, R., T. Zemlak, B. Innes, P. Last \& P. Hebert. 2005. DNA barcoding Australia \& apos. Philos Trans R Soc Lond B, 360.

Wargasasmita, S. 2005. Ancaman invasi ikan asing terhadap keanekaragaman ikan asli. Jurnal Iktiologi Indonesia. 5 (1): 510.

Wibowo, A., R. Affandi, K. Soewardi \& S. Sudarto. 2010. Genetic differentiation of the kampar river's giant featherback (Chitala Lopis Bleeker 1851) Base on mitochondrial DNA analysis. Ind.Fish Res.J. 16 (2): 49-58.

Yustysi, D.P., F. Basuki, T. Susilowati \& T. Yuniarti. 2016. Analisis karakter reproduksi dan performa benih hibrid ikan nila pandu f6 dengan ikan nila nilasa (Oreochromis niloticus). Indonesian Journal of Fisheries Science and Technology. 12 (1): 19-23.

Zemlak, T.S., R.D. Ward, A.D. Connell, B.H. Holmes \& P.D.N. Hebert. 2009. DNA barcoding reveals overlooked marine fishes. Molecular Ecology Resources. 9 (SUPPL. 1), 237-242. https://doi.org/ 10.1111/j.1755-0998.2009.02649. 